\title{
Ranching and Multiyear Droughts in Utah: Production Impacts, Risk Perceptions, and Changes in Preparedness
}

\author{
D. Layne Coppock \\ Author is Associate Professor, Environment \& Society Department, Utah State University, Logan, UT 84322-5215, USA.
}

\begin{abstract}
Droughts characterize rangelands, yet drought research remains limited. Objectives of the study were to determine: 1) effects of the 1999-2004 drought on ranch resources, 2) how ranchers coped with the 1999-2004 drought, 3) whether ranchers have altered their preparedness for future drought, and 4) factors influencing change in preparedness. A phone and mail survey engaged a random sample of 615 ranchers providing 509 usable responses $(83 \%)$. Data analysis employed descriptive statistics, directional change tests, and logistic regression. Compared to "normal" years, the 1999-2004 drought had negative effects on $75 \%$ of operations including major reductions in water supplies, forage, and cattle productivity. One quarter of respondents indicated that the drought had neutral or positive effects, usually because they had unhindered access to water or high-value hay. Only $14 \%$ of respondents felt they were adequately prepared for the 1999-2004 drought, illustrated by the high use of federal relief programs and involvement in crisis-related water development, livestock sales, and hay purchases. The "drought trap" was financial (lower revenue and higher costs), with effects well beyond 2004. By 2009 preparedness had reportedly changed. Twenty-nine percent of respondents felt they were better prepared for drought in 2009 than in 1998, a significant shift $(P \leq 0.01)$ in the population. Increased preparedness was significantly associated $(P \leq 0.02)$ with how badly a rancher was affected by the 1999-2004 drought as well as their belief that another drought is imminent. Risk-management tactics now include investment in natural-resource development and conservation plans, reductions in stocking rates, income diversification, and enrollment in insurance and federal disaster-assistance programs. Sixty-one percent of respondents said they were actively planning for future drought. The lessons of 1999-2004 have increased awareness of drought hazards among Utah ranchers, providing opportunity to enhance the financial and ecological sustainability of ranching via well-conceived risk-management initiatives.
\end{abstract}

\section{Resumen}

Las sequías son características de los pastizales, sin embargo, las investigaciones sobre la sequía sigue siendo limitada. Los objetivos de este estudio fueron determinar: 1) efectos de la sequía de 1999-2004 en los recursos de un rancho, 2) cómo los ganaderos enfrentaron a la sequía de 1999-2004, 3) si los ganaderos han cambiado su preparación para futuras sequías y 4) los factores que influyen en el cambio en la preparación para la seguía. Se utilizó una encuesta por correo y telefónica tomando muestras al azar de 615 ganaderos de los cuales se recibieron 509 cuestionarios (83\%). Para el análisis de los datos se utilizaron estadísticas descriptivas, pruebas de cambio de dirección y regresión logística. En comparación con años "normales” la sequía de 1999-2004 tuvo un efecto negativo en el 75\% de las operaciones incluyendo importantes reducciones en el suministro de agua, forraje, y productividad del forraje. Una cuarta parte de los encuestados indicó que la sequía tuvo efectos neutros o positivos, ya que se tuvo acceso sin restricción al agua o a heno de buena calidad. Solamente el $14 \%$ de los encuestados consideró estar preparados adecuadamente para la sequía de 1999-2004, demostrado por el alto uso de programas de ayuda federal y la participación en programas de crisis de agua, venta de animales y compra de heno. La "trampa de la sequía" fue financiera (pocas ganancias y altos costos) con efectos más allá del 2004. Para el 2009 la preparación al parecer había cambiado. Veintinueve por ciento de los encuestados consideró que estaban mejor preparados para la sequía del 2009 que en 1998, un cambio significativo $(P \leq 0.01)$ en la población. Un incremento en la preparación estuvo significativamente asociado $(P \leq 0.02)$ con la severidad del daño por la sequia de 1999-2004, así como su convicción de que otra sequía es inminente. Los planes de manejo de riesgos ahora incluyen la inversión en el desarrollo de los recursos naturales y planes de conservación, reducción en la carga animal, diversificación de ingresos y la inscripción en los programas de asistencia de desastre federal. El $61 \%$ de los encuestados mencionaron que planeaban activamente para futuras sequías, Las lecciones de 1999-2004 han hecho más consciente de los riesgos de la seguía entre ganaderos de Utah, proporcionando la oportunidad de mejorar la sostenibilidad financiera y ecológica de la producción de ganado a través de iniciativas de de manejo de riegos bien planeado.

Key Words: adaptive management, climate change, policy, range livestock, risk management, social-ecological systems

Research was supported as part of Utah Agricultural Experiment Station project UT919. Approved as journal paper 8215

Correspondence: D. Layne Coppock, Environment \& Society Dept, Utah State University, Logan, UT 84322-5215, USA. Email: Layne.Coppock@usu.edu

Manuscript received 8 July 2010; manuscript accepted 27 June 2011.

\section{INTRODUCTION}

Drought is common in arid and semiarid ecosystems. Drought is an important global hazard in terms of the numbers of people affected (Hayes et al. 2004). Definitions of drought include meteorological, agricultural, hydrological, or socioeconomic 
dimensions (Thurow and Taylor 1999; UDWR 2007-2008). Multiyear droughts can have very negative effects on crop and animal production systems. In eastern Africa, for example, recurrent droughts decimate livestock herds, bringing destitution and famine among pastoralists (Desta and Coppock 2002, 2004). In the western United States, although economic development and public safety nets help mitigate extreme drought effects on rural communities, the social, economic, and environmental costs remain substantial. The last multiyear drought in Utah (1999-2004) contributed to across-the-board production losses for farms and ranches of at least $30 \%$, with an estimated cumulative loss of $\$ 133$ million to Utah's agricultural economy (UAS and UDAF 2004). This was a regional drought that also affected several neighboring states (Miller 2005; Bastian et al. 2006).

The 1999-2004 drought has been one of six "significant droughts" for Utah since 1898 based on the Palmer Drought Severity Index (PDSI; UDWR 2007-2008). The average length of these droughts is $8.5 \mathrm{yr}$ (range: 4-19 yr) with interdrought periods averaging $12.0 \mathrm{yr}$ (range: 7-23 yr). Since 1970 there have been three major Utah droughts (1976-1979, 1987-1992, 1999-2004). Some climate-change scenarios indicate that parts of the Intermountain West may become drier and hence more drought-prone (Wagner and Baldwin 2003; UDWR 20072008).

Given the importance of drought and climate change it is remarkable that detailed drought research at the ranch operational level remains uncommon. Most drought research is dominated by broader-scaled studies of climate, weather monitoring, policy, and regional planning processes (Dettinger 2003; Hayes et al. 2004; Jacobs et al. 2005; NDMC 2010). Bastian et al. (2006) is a rare exception where effects of the 2000-2004 drought on 814 Wyoming ranchers were surveyed using a random sample. They found that each consecutive year of drought and operation size influenced ranch droughtresponse strategies. In modeling work, Coppock et al. (2009) underscored the key importance of hay markets, grass banks, diverse forage resources, and larger ranch sizes in promoting improved risk management for ranchers during drought. Molinar et al. (1999) described drought research as one priority for applied rangeland science, including subtopics such as climate patterns, ranch risk management, and droughtrelevant grazing systems.

Other work pertinent to ranching has usually been summarized in review or concept papers that focus on drought definitions, policy, or general management perspectives (Boykin et al. 1962; Holechek et al. 1994, 1999; Holechek 1996a, 1996b; Thurow and Taylor 1999; Ward 1999; Dunn et al. 2005; Miller 2005; Schwinning et al. 2008; George et al. 2010). Major droughts are slow-onset or "creeping" hazards, that once perceived, require management decisions to be made quickly under uncertainty. Whether a rancher should or could destock in a crisis is a core question that involves many economic and ecological considerations. Authors cited above repeatedly echo themes important for improving drought management, prominently including that ranchers regularly use conservative stocking rates that provide the most income for the least risk. Other factors include ranchers having management flexibility and diversified livelihoods as well as avoiding episodes of severe overgrazing and crisis-induced debt. Government drought-assistance programs-abundant and growing for decades-are often criticized as being too politically influenced and providing perverse incentives for ranchers. Subsidies take many forms and can be seen as rewards to producers who were either too heavily stocked predrought or otherwise poorly managed their operations, and hence require a bailout. The ecological condition of the supporting rangelands then suffers as another outcome.

The field of risk management is very relevant to rangeland drought management, especially concerning how producers perceive drought risk and the extent to which they actively prepare for drought. Although it may seem obvious that ranchers should always be vigilant, experience tells us otherwise. Whether or not the resource in question is rainfall, human nature often promotes blissful enjoyment of "normal or boom times" while discouraging preparedness for the inevitable "busts." An important issue is whether there are adequate incentives for ranchers to become more proactive risk managers rather than victims of recurrent crisis. Dunn et al. (2005) mentioned that four factors inhibit South Dakota ranchers from being more proactive, namely their "mental models," financial considerations, policy barriers, and drought scale. Others note the "teachable moments" that only a drought-crisis experience provides, perhaps leading to shifts in future drought preparedness (Miller 2005). This is consistent with theory that past negative experiences and awareness of recurrent threat can lead to changes in human response patterns (Johnson and Scicchitano 2000; O'Connor et al. 2005).

Using a survey approach for the Utah ranching population, this exploratory research was designed to meet the following objectives: 1) determine impacts of the 1999-2004 drought on ranch resources and cattle productivity as perceived by ranchers, 2) determine how ranchers coped with the 19992004 drought, 3) determine whether ranchers have altered their preparedness for future drought, and 4) identify important factors influencing change in the level of drought preparedness. The work was intended to yield insights for risk management theory as well as inform practical application for drought management interventions.

\section{METHODS}

\section{Study Area}

About half of Utah's 5000 -plus cattle ranches in the mid- to late 1990s relied solely on privately owned or privately leased grazing lands, while the other half relied on a combination of private land and public grazing permits (Peterson and Coppock 2001). This general pattern probably prevails today. Land in Utah is owned by the federal government $(68.8 \%)$, state government $(10.0 \%)$, or private entities $(21.1 \%$; LeydsmanMcGinty 2009). The forage resources on private grazing lands tend to be more productive than those on public grazing lands (Coppock et al. 2009). Compared to permittees, ranchers wholly dependent on private grazing tend to have smaller brood herds and less reliance on ranch income, but both groups are very heterogeneous in terms of social and economic features (Coppock and Birkenfeld 1999; Peterson and Coppock 2001).

General patterns of seasonal herd productivity and resource use by Utah cow-calf operations are described by Godfrey 
(1992). The annual production cycle begins in early spring (late February and March) with calving on private land near the home ranch. Brood cows and calves are fed hay until spring and summer grazing becomes available on private or public lands. Calves are weaned in September and October and finished to a slaughter weight by ranchers or feedlot operators. The brood herd may forage on crop aftermath or private pastures until snow makes hay-feeding necessary, typically by December. Utilization of public grazing often follows a seasonal pattern that varies with elevation: namely, low-elevation desert range in winter, midelevation foothill range in spring and fall, and high-elevation mountain range in summer. The desert permits are typically administered by the Bureau of Land Management (BLM) of the US Department of the Interior, whereas permits used in foothill and mountain allotments are administered by the Forest Service (USFS) of the US Department of Agriculture (USDA). Eligibility for grazing permits has been historically founded on a permittee having deeded private ground. Such operations often include fields for irrigated hay production and access to permanent water (Coppock et al. 2009).

As will be shown, Utah ranchers today have an expanding array of options to help them prepare for, and respond to, drought. Such options primarily influence how brood herds and private lands are managed-basic resources that all Utah operations have in common. Study of the decisions that pertain to the management of privately held resources can reveal important and generalizable aspects of rancher behavior, and that was the ultimate goal of this research. There is little doubt, however, that the administration of public grazing would also affect how Utah grazing permittees cope with drought. Drought policy for BLM and USFS lands was thus initially explored via discussions with federal experts.

\section{Survey Design and Implementation}

The Utah Field Office of the USDA National Agricultural Statistics Service (NASS) was commissioned to assist with this research. The survey instrument was created at Utah State University (USU), but survey implementation was conducted by NASS according to their standard survey procedures. A simple random sample of 615 operations was drawn from the Utah sampling frame comprising 1606 total beef operations known to NASS. The sampling frame is continuously updated using many sources, including lists of participants in various state and federal programs. The sampling frame covers $95 \%$ of private ranch land in Utah as well as $65 \%$ of beef producers (J. Gentillon, personal communication, December 2010). The producers who are missed typically generate $<\$ 1000$ in annual beef-derived revenue, typically having five or fewer head of beef cows. The sample size was targeted to obtain at least 500 usable responses.

The survey was piloted, refined, and mailed out in a packet including a letter of information approved by the Institutional Review Board, a double-sided page with a glossary of key terminology to facilitate survey implementation, and an addressed, prepaid envelope for returning completed surveys. The first wave of packets was sent to all 615 members of the sample during early February 2009. Of these, 146 (23.7\%) were completed and sent back to the NASS field office. A second wave of packets was sent out at the end of February to the nonrespondents. Another 61 completed surveys resulted, bringing the cumulative total to 207 (33.6\%). A telephone phase began in mid-March to capture the remaining nonrespondents. Highly experienced NASS enumerators assisted respondents in completing the survey by telephone, requiring an average of $25 \mathrm{~min}$ each. This generated another 372 completed surveys, with the cumulative total at 579 (94\%). Finally, 16 surveys from otherwise inaccessible respondents were completed via face-to-face contact between operators and NASS staff when NASS staff made routine site visits across the state. The grand total for completed surveys became 595 $(96.7 \%)$. In a few cases operators who had submitted surveys by mail were recontacted by phone in April and May to clarify their written responses when data were being cleaned and processed.

The intended survey recipient was the primary decision maker for each operation. Both men and women commonly participated in the survey, but we did not count respondents according to gender. The survey had 53 short-answer or multiple-choice questions (copy available from the author). Questions covered the following topics: 1) background descriptions for respondents including age, formal education, ranching experience, how they make ranching decisions in general, age of their operation, and size of their brood herd; 2) perceptions of respondents concerning previous drought impacts from 1999-2004; 3) respondent recall concerning emergency tactics used to cope with the 1999-2004 drought; 4) risk-management tactics currently used by respondents to prepare for the next multiyear drought; and 5) how respondents make specific decisions concerning drought preparedness, with a focus on future drought expectations, levels of grazing utilization and stocking rates, use of drought early-warning systems, and self-assessment rankings as a drought manager; their ideas were also solicited for technologies, policies, or programs that could help them improve their level of drought preparedness.

The most common tactics for coping with drought emergency response and predrought risk management were narrowed to eight and 15, respectively, based on literature review and opinions of state and federal experts. Most tactics are selfexplanatory, but a few points of clarification are provided here. Government emergency-response programs primarily included access to supplemental feeds, supplemental water, or financial or marketing services, and these are initiated when a county is declared a "disaster area" (all 29 Utah counties received this designation during 1999-2004). Private sources of emergency relief included resources donated by family, friends, church, etc. Risk management tactics included use of 1) grass banks on public or private lands, 2) feed insurance (from public and private sources) that help cover losses of high-value (irrigated) feeds, 3 ) enrollment in federal disaster-compensation programs that help cover losses of livestock and nonirrigated forage production that are uninsurable, and 4) government cost-share programs to restore forage productivity under normal and drought conditions.

Seven local experts from federal agencies and academia were specifically engaged-via email, phone, and face-to-face conversations-to advise on a few aspects of research design and assist with interpretation of key results; their input is noted here as personal communication. Such insights are valuable 
because of the interdisciplinary and complex nature of drought management interventions. All data collection was completed by May 2009 and data were processed by NASS using SAS/ STAT software Version 8.3 in the SAS System for Windows.

\section{Statistical Analyses}

Data for qualitative, short-answer questions were collated by response and tallied. For questions with quantitative responses, descriptive statistics were computed and distributions were visually assessed using histograms. Selected bivariate patterns were inspected using cross-tabulated tables, side-by-side box plots, or scatter plots, as appropriate. Binomial confidence intervals (CI) were computed at the $95 \%$ level for proportional data using an online tool (Creative Research Systems 2007).

Using responses to questions concerning self-assessed levels of predrought preparedness in 1998 and 2009, the McNemar test for directional change (Uebersax 2006) was used to statistically test whether respondents were consistently more or less prepared in 2009 compared to 1998 . Based on the same self-assessments, respondents were scored with respect to consistent or transitional behavior. Those respondents with identical self-assessments for both years were assigned consistency scores of "prepared," "somewhat prepared," or "unprepared." Respondents with differing self-assessments for the $2 \mathrm{yr}$ were assigned transition scores of "more prepared" or "less prepared" when comparing 2009 to 1998.

Transitional shifts in drought preparedness were of particular interest. Causal factors thought to influence drought preparedness comprise hypotheses and included the following: 1) income, 2) ranch location, 3) whether or not respondents were public grazing permittees, 4 ) degree of ranch management experience, 5) previous use of drought crisis-response tactics, 6) level of formal education, 7) operator age, 8) degree that previous drought had negatively affected their operations, and 9) whether an operator expected another multiyear drought to occur soon. The rationale for proposing these factors as priorities is as follows: 1) higher incomes are associated with a higher risk tolerance and greater ability to invest in operational improvements (Peterson and Coppock 2001), therefore higher incomes could be associated with increasing drought preparedness; 2) Utah has seven distinct climate regions (UDWR 2007-2008) and thus location might affect the degree to which operations are exposed to multiyear droughts; 3 ) being a public grazing permittee is associated with a producer having more of a business orientation compared to private-land-only operators (Peterson and Coppock 2001), and this orientation may contribute to heightened awareness concerning drought planning; 4) years of experience as a ranch manager could affect drought preparedness, especially when considering newer owners/operators who have gotten into ranching from other professions and who may have little or no previous experience with multiyear droughts (S. Green, personal communication, October 2008); 5) level of formal education, with particular attention to access to tertiary education that can increase exposure to agribusiness training and risk-management tools and techniques; 6) operator age that can be directly related to ranch management experience; and 7) degree of exposure to previous drought impacts—such experience, in conjunction with expectations of imminent drought, can heighten perceptions of recurrent environmental threats and motivate changes in behavior (Baldassare and Katz 1992; O'Connor et al. 1999; Johnson and Scicchitano 2000).

From the list of nine factors we were able to collect direct empirical data for all items except income in our survey. We therefore used brood herd size as a proxy for ranch-derived income. We also had to condense the seven climate regions of Utah into five to reduce problems of insufficient or widely imbalanced observations for categorical analyses. Our five regions left the Western, Uinta, and South-Central regions the same as in UDWR (2007-2008) but combined the Northern Mountains with the North-Central region and the Southeast with the Dixie region. The resulting five regions still had ecological relevance but had a minimum of 65 sampled operations.

The association between transition and each selected quantitative variable (i.e., herd size, numbers of actions taken, and years of rancher experience, formal education, and age) was assessed using linear logistic regression. The appropriateness of the linearity assumption was evaluated using the Hosmer-Lemeshow test. Because consistency is an ordered response with three levels, the association between consistency and each quantitative variable was summarized using ordinal logistic regression with cumulative logits. The appropriateness of the cumulative logit model was tested using the score test for the proportional odds assumption. The association between transitional behavior and each selected qualitative variable (i.e., region, whether the respondent was a permittee, effect of the 1999-2004 drought, and expectation of future drought) was assessed using a $\chi^{2}$ test of independence. Similar analyses were conducted for associations with consistent management behavior. The $\chi^{2}$ test of independence was also used to analyze associations between rancher perceptions of current stocking levels (low, medium, high) in relation to self-declared decisions regarding whether they are altering stocking rates as a predrought risk-management tactic. Unless otherwise noted, all computations at USU were made using the SAS/STAT software Version 9.1.3 in the SAS System for Windows. All statistical analyses used a significance threshold of $P \leq 0.05$.

\section{RESULTS}

\section{Target Population and Past Drought Effects}

The $96.7 \%$ survey response rate is primarily a testament to the positive relationship between NASS and their ranching clientele, as well as the skills and diligence of enumerators conducting the telephone component. The core of the survey had been honed down to only three pages, thus ease of completion-as well as the perceived importance of the topicmay also have contributed to the high response rate. Of the 595 responses, 509 were usable for the research. The 86 unusable responses were primarily from people who had recently decided to get out of the beef business, either temporarily or permanently. All 29 Utah counties were represented among the respondents. The percentage of public grazing permittees was $63 \pm 4.4 \%$ (95\% CI here and henceforth), consistent with estimates from previous statewide research (Peterson and Coppock 2001). 
Table 1. Features of Utah cattle ranches and ranchers in 2009. ${ }^{1}$

\begin{tabular}{lccc}
\hline \multicolumn{1}{c}{ Variable } & $n$ & Median & \multicolumn{1}{c}{ Comments } \\
\hline Brood herd size & 497 & 135 head & $\begin{array}{l}5 \% \text { had } \leq 5 \text { head; } \\
18 \% \text { had } \geq 300 \text { head }\end{array}$ \\
Age of operation & 483 & $41 \mathrm{yr}$ & $\begin{array}{l}6 \% \text { began before } 1900 ; \\
58 \% \text { began during } 1951-2000 ; \\
\end{array}$ \\
& & & $3 \%$ began after 2000
\end{tabular}

${ }^{1}$ Data for these variables were highly skewed, precluding the use of means as descriptors.

Descriptive data for operations and operators are shown in Table 1. There was a wide range of brood-herd sizes. Operations have typically been established for a long time and are run by middle-aged, well-experienced managers. When asked how they make management decisions, $92 \pm 2.7 \%$ of respondents agreed that they "use a mixture of tradition and new ideas."

Effects of the 1999-2004 drought as perceived by all ranchers surveyed are shown to the left in Table 2. In general, trends suggested that drought effects were greater on forage and water resources compared to those for livestock. Property values were considered to be unaffected. When asked to describe the overall effect of the drought on their operations using a five-point scale, the following was estimated: $16 \pm$ $3.1 \%$ of all respondents scored the effect as "very bad," $59 \pm 4.7 \%$ as "bad," $20 \pm 3.6 \%$ as "neutral," $4 \pm 1.9 \%$ as "good," and $<1 \%$ as "very good." When the perceived effects of drought were compared between the $75 \%$ of respondents noting negative influences vs. the $25 \%$ noting neutral or positive influences, a pattern was evident that supported the self-categorizations (see the center and right-hand columns of Table 2). This suggests that drought effects widely varied across the population.

Respondents were given an opportunity to describe in openended responses why they scored the overall effect of drought as they did. There were 569 comments from 334 respondents as to why drought effects were perceived as "very bad" or "bad." The most fundamental scenario-supported by 509 comments-was the financial burden of reduced profitability due to lowered revenue, in conjunction with increased operating costs caused by drought. Reduced supplies of water, grazing, and crops (i.e., alfalfa hay, cereal residues) led to reduced calf numbers and weaning weights, while increased sales volume for some animal classes (brood cows) led to lower prices within a year after the drought began. Brood herds needed to be culled or subsidized in terms of procuring suddenly expensive forage and water supplies. Cost burdens were most often mentioned in terms of emergency hay purchase (96 comments), followed distantly by the need to haul water or drill for water (16 comments), trucking animals to neighboring states (14 comments), the opportunity cost of feeding vs. selling hay (12 comments), leasing additional grazing land (11 comments), and increased time needed for crisis management (five comments). In a few cases, respondents noted that there were added negative effects from range fires on public lands that further reduced forage supplies during drought. Twenty respondents said that negative effects of the 1999-2004 drought still persisted in 2009. Examples included the economic penalty of selling brood cows during drought at lower prices followed by postdrought restocking at markedly higher prices, losing investments in previous range improvements, and incurring high levels of crisis-related debt.

There were 52 reasons from 89 respondents to open-ended questions as to why drought effects were perceived as "neutral," "good," or "very good." The most frequently mentioned reason (24 comments) was that operators had unhindered access to water from streams, rivers, or reservoirs, allowing cattle to forage on irrigated pasture and/or maintaining the ability to produce irrigated hay for consumption or sale. The second most mentioned reason (nine comments) was that their nonirrigated grazing resources were adequate, whether due to a higher grazing land quality, greater access to grazing land, or preplanned reductions in stocking rates that increased forage supply under drought conditions. The third most mentioned reason (six comments) was that operators had taken precautions to store extra hay prior to drought. Other minor reasons for mitigated drought effects included the positive impact of government relief programs, producer access to diversified financial resources, and the ability of some operators to move cattle locally or regionally. For the latter this included access to out-of-state markets for the sale of stocker cattle.

\section{Drought Coping Tactics-Past and Present}

Crisis-response tactics of ranchers in 1999-2004 are shown in Table 3. Overall, use of emergency options was high. Enrollment in government relief programs as well as emergency hay

Table 2. Effects of the 1999-2004 drought on ranch attributes as perceived by Utah ranchers in 2009. ${ }^{1}$

\begin{tabular}{|c|c|c|c|c|c|c|}
\hline \multirow[b]{2}{*}{ Variable } & \multicolumn{2}{|c|}{ All respondents } & \multicolumn{2}{|c|}{ Respondents reporting negative effects } & \multicolumn{2}{|c|}{ Respondents reporting neutral/positive effects } \\
\hline & $n$ & Median & $n$ & Median & $n$ & Median \\
\hline Grazing capacity & 462 & $30 \%$ decline & 355 & $33 \%$ decline & 102 & $20 \%$ decline \\
\hline Water supply & 459 & $33 \%$ decline & 357 & $40 \%$ decline & 99 & $20 \%$ decline \\
\hline Hay production & 452 & $30 \%$ decline & 343 & $30 \%$ decline & 103 & $18 \%$ decline \\
\hline Cattle sale weights & 443 & $10 \%$ decline & 339 & $10 \%$ decline & 98 & $0 \%$ (no change) \\
\hline Brood herd number & 460 & $15 \%$ decline & 354 & $20 \%$ decline & 99 & $0 \%$ (no change) \\
\hline Property value & 325 & $0 \%$ (no change) & 252 & $0 \%$ (no change) & 68 & $0 \%$ (no change) \\
\hline
\end{tabular}

${ }^{1}$ Data for these variables were highly skewed, precluding the use of means as descriptors. 
Table 3. Crisis-response tactics used by Utah ranchers during the 1999-2004 drought.

\begin{tabular}{|c|c|c|}
\hline Tactic $^{1}$ & $n$ & $\begin{array}{l}\text { Percentage of respondents }( \pm 95 \% \\
\text { CI) saying "Yes, I did this" }\end{array}$ \\
\hline $\begin{array}{l}\text { Enrolled in government relief } \\
\text { programs }\end{array}$ & 498 & $68 \pm 4.6 \%$ \\
\hline $\begin{array}{l}\text { Relied on emergency purcha } \\
\text { of hay }\end{array}$ & 495 & $66 \pm 4.3 \%$ \\
\hline $\begin{array}{l}\text { Relied on emergency sales } 0 \\
\text { livestock }\end{array}$ & 497 & $53 \pm 4.4 \%$ \\
\hline $\begin{array}{l}\text { Obtained emergency water } \\
\text { Relied on emergency truckin }\end{array}$ & 493 & $36 \pm 4.1 \%$ \\
\hline to move livestock & 493 & $28 \pm 4.1 \%$ \\
\hline Claimed tax write-offs & 493 & $26 \pm 3.8 \%$ \\
\hline Renegotiated bank loans & 493 & $23 \pm 3.9 \%$ \\
\hline Other ${ }^{2}$ & 493 & $15 \pm 3.2 \%$ \\
\hline $\begin{array}{l}\text { Obtained relief from private } \\
\text { sources }\end{array}$ & 492 & $5+18 \%$ \\
\hline $\begin{array}{l}{ }^{1} \text { Most tactics are self-explanator } \\
{ }^{2} \text { There were } 19 \text { tactics reporte } \\
\text { expanding grazing land and in } \\
\text { in water improvements (six re } \\
\text { (four responses), 4) seeking } \\
\text { rather than selling hay (three }\end{array}$ & Met & $\begin{array}{l}\text { Is section for details. } \\
\text { category. The most common were: 1) } \\
\text { iprovements (six responses), 2) investing } \\
\text { cing consumption by household members } \\
\text { on (four responses), and 5) feeding hay }\end{array}$ \\
\hline
\end{tabular}

purchase dominated the tactics used. Few ranchers obtained relief from private sources.

When respondents $(n=506)$ indicated whether or not they expected a major drought to occur in the coming decade (i.e., 2009-2019), the majority-54 $\pm 4.1 \%$ —said "yes"; a minority$11 \pm 3.1 \%$ - said "no"; and the remaining $35 \pm 4.0 \%$ said they "did not know." Given this background, the reported use of risk-management tactics in anticipation of a coming drought was over $50 \%$ in six of 15 major categories; the most common tactics focus on water development, income diversification, reduction of stocking rates, and investment in land management (Table 4). The tactics less commonly used include forward contracting for hay purchase and renegotiation of bank loans.

About twice as many respondents perceived that they are currently "prepared" for the next multiyear drought as compared to the predrought period of the late 1990s $(P<0.05$; Table 5$)$. In a related question, respondents were asked if they were actively planning for the next drought. A total of $n=502$ responded, and of these $61 \pm 0.05 \%$ said they strongly agreed or agreed. A total of $9 \pm 0.02 \%$ said they disagreed or strongly disagreed. The remaining $30 \pm 0.04 \%$ had no opinion. This supports the idea that a majority of the target population is aware of the need to prepare for multiyear drought.

Table 6 illustrates that $35 \%$ of respondents (i.e., 166/469) perceived that they consistently remained "somewhat prepared" in both the predrought situations of 1998 and 2009, whereas a minority were either consistently "prepared" $(10 \%$; 49/469) or consistently "unprepared" (9\%; 45/469). There was a shift to increased drought preparedness $(P<0.01$; McNemar), with the remaining respondents stating they were in a transition phase, either moving from less to more preparedness ( $n=165$ or $35 \%$; see the three cells to the lower left corner of
Table 4. Risk-management tactics used by Utah ranchers in 2009 for drought preparedness.

\begin{tabular}{|c|c|c|}
\hline Tactic $^{1}$ & $n$ & $\begin{array}{l}\text { Percentage of respondents }( \pm 95 \% \\
\mathrm{Cl}) \text { saying "Yes, I am doing this" }\end{array}$ \\
\hline Improving water for livestock & 499 & $76 \pm 4.0 \%$ \\
\hline Diversifying family income & 493 & $68 \pm 4.4 \%$ \\
\hline \multicolumn{3}{|l|}{ Improving irrigation for hay } \\
\hline production & 491 & $67 \pm 4.3 \%$ \\
\hline Improving land management & 497 & $57 \pm 4.5 \%$ \\
\hline Reducing stocking rates & 502 & $56 \pm 4.9 \%$ \\
\hline \multicolumn{3}{|l|}{ Enrolling in government disaster } \\
\hline compensation programs & 501 & $55 \pm 5.0 \%$ \\
\hline \multicolumn{3}{|l|}{ Increasing capacity for hay } \\
\hline production & 495 & $53 \pm 4.4 \%$ \\
\hline Purchasing feed insurance & 500 & $38 \pm 3.9 \%$ \\
\hline Seeking extension information & 497 & $37 \pm 3.8 \%$ \\
\hline Using internet drought forecasts & 493 & $31 \pm 4.2 \%$ \\
\hline \multicolumn{2}{|l|}{ Using forward contracting for } & $30 \pm 4.2 \%$ \\
\hline \multicolumn{3}{|l|}{ Increasing capacity for hay } \\
\hline storage & 501 & $29 \pm 3.8 \%$ \\
\hline Planning to use grass banks & 495 & $26 \pm 3.7 \%$ \\
\hline Renegotiating bank loans & 498 & $17 \pm 3.5 \%$ \\
\hline Other ${ }^{2}$ & 509 & $9 \pm 2.3 \%$ \\
\hline \multicolumn{3}{|l|}{ Using forward contracting for } \\
\hline
\end{tabular}

${ }^{1}$ Most tactics are self-explanatory. See the Methods section for details.

${ }^{2}$ There were 19 tactics reported for the "Other" category. The most common were: 1) expanding grazing land and investing in improved grazing systems (seven responses), and 2) researching aspects of drought and drought management (two responses).

the matrix) or from more to less preparedness (9\%; see the three cells to the upper right corner of the matrix).

Multivariate analyses did not reveal useful patterns concerning factors influencing increased drought preparedness; however, some results from univariate analyses were significant $(P \leq 0.05$; Table 7). Several factors promoted a shift toward increased drought preparedness including regional residence, negative experience with the 1999-2004 drought (actions and impacts), as well as expectations that the next drought is imminent. Regional residence patterns indicated that respondents from the Uinta and South-Central climate regions were most likely to have increased drought preparedness, while those from the North/North-Central regions were least likely to have done so. Respondents from the Southeast/Dixie and Western regions were intermediate. Numbers of actions taken during

Table 5. Perceptions of past and current drought preparedness among Utah ranchers. ${ }^{1}$

\begin{tabular}{lcc}
\hline \multicolumn{1}{c}{ Response } & $1998(n=504)$ & $2009(n=504)$ \\
\hline Prepared & $14 \pm 3.2 \%$ a & $29 \pm 3.6 \% \mathrm{~b}$ \\
Somewhat prepared & $54 \pm 4.9 \%$ a & $51 \pm 4.3 \%$ a \\
Unprepared & $29 \pm 4.0 \%$ a & $16 \pm 3.4 \% \mathrm{~b}$ \\
Don't know & $4 \pm 1.7 \%$ a & $4 \pm 1.7 \%$ a \\
\hline
\end{tabular}

${ }_{1}^{1} 1998$ represents the period prior to the 1999-2004 drought. Data entries are $95 \%$ confidence intervals. Entries in the same row followed by different letters $(a, b)$ were significantly different $(P \leq 0.05$.$) .$ 
Table 6. Perceptions of past and current drought preparedness among Utah ranchers. ${ }^{1}$

\begin{tabular}{lcccr}
\hline \multirow{2}{*}{$\begin{array}{c}\text { Past drought } \\
\text { preparedness (1998) }\end{array}$} & \multicolumn{3}{c}{ Current drought preparedness (2009) } & \\
\cline { 2 - 4 } & Prepared & Somewhat prepared & Unprepared & Sum \\
\hline Prepared & 49 & 13 & 5 & 67 \\
Somewhat prepared & 69 & 166 & 26 & 261 \\
Unprepared & 25 & 71 & 45 & 141 \\
Sum & 143 & 250 & 76 & 469 \\
\hline
\end{tabular}

${ }^{1} \mathrm{~A}$ total of 19 respondents ( $4 \%$ of the total) were unable to rank themselves at both points in time and were excluded from this analysis.

the 1999-2004 drought across all respondents varied from zero to eight (Table 3). Impacts of the 1999-2004 drought were aggregated as "bad/very bad" or "neutral/good/very good" (Table 2).

Multivariate and univariate analyses were conducted on data for ranchers that remained consistent in their level of drought preparedness between 1998 and 2009, but no significant patterns were revealed. Because the number of ranchers exhibiting a trend toward less preparedness between 1998 and 2009 was low $(n=44)$ we did not conduct similar analyses for this group.

Respondents were asked to list factors important in helping them decide whether an extended drought is upon them and therefore, when it may be time to sell cattle or make other crisis management responses. A total of 387 respondents answered this question and gave 443 useful remarks. The most common factors were: 1 ) low snowpack (164 responses or 37\%), 2) low spring or summer rainfall (70 responses or $18 \%$ ), 3) lack of forage during the growing season (39 responses or 9\%), 4) low reservoir levels and limitations on irrigation water (24 responses or $5 \%), 5$ ) weather forecasts on television or the Internet (14 responses or 3\%), 6) cuts in public grazing permits (13 responses or 3\%), and 7) drying up of springs, ponds, and wells (12 responses or $3 \%$ ). Descending cattle prices, ascending hay prices, or other economic indicators were only mentioned 13 times overall. Warmer temperatures or persistent dry winds were mentioned 13 times as signals of major drought. Poor condition of rangeland or livestock was mentioned eight times. A total of 44 respondents noted the joint occurrence of low snowpack followed by low rainfall in spring and/or early summer as the key indicator they used. This was, perhaps, the most insightful response given.

Given that stocking-rate reduction was commonly mentioned as a risk-management tactic for 2009 (Table 4), it became important to assess whether it was associated with declared stocking level (light, moderate, heavy) posed in a subsequent question. This was an opportunity to cross-check information. Results indicated that operators who said they have reduced stocking levels also perceived that they use lighter stocking levels compared to those who have not altered stocking levels (Table $8 ; P=0.01$ ). This therefore provided some measure of validation for this information.

We also generated information on producers' self-assessments of grazing utilization by asking "what percentage of standing forage is typically removed" on their private ground by the time winter sets in, considering "the last few years." This generally referred to 2005-2008, a period that largely had a "normal" precipitation regime. Responses to this question were diverse. For 366 respondents, the following breakdown was observed: 1) $27 \%(n=100)$ said they removed $\geq 81 \%$ of standing forage, 2$)$ $45 \%(n=167)$ said they removed $61-80 \%, 3) 18 \%(n=67)$ said they removed $41-60 \%, 4) 6 \%(n=23)$ said they removed $21-40 \%$, and 5) $2 \%(n=9)$ said they removed $\leq 20 \%$. An overall weighted average for these data, only for illustrative purposes and using category midpoints, is $68 \%$. Using the same $\chi^{2}$ analytical format as depicted in Table 8 , there was no significant association in this case of perceived grazing utilization with self-declared stocking levels $(P=0.91)$.

Similarly, it also became of interest to assess whether stocking-rate reduction tactics were associated with income diversification. The latter was also often mentioned as a riskmanagement tactic (Table 4), and it is logical that a reduced dependence on ranch-derived income could allow more flexibility in rangeland management (Table 4). However, this potential association-evaluated using a similar $\chi^{2}$ approachwas also not significant $(P=0.32)$.

Drought Management-Rancher Self-Assessments and Needs Finally, respondents were asked to rank themselves as drought managers. A total of 502 replied as follows: Excellent $(4 \pm$ $0.01 \%)$, good $(32 \pm 0.04 \%)$, average $(48 \pm 0.05 \%)$, fair $(9 \pm$ $0.03 \%)$, and poor $(7 \pm 0.02)$. When asked what could help respondents become better drought managers, 282 respondents

Table 7. Results from univariate analyses for factors associated with changes in drought preparedness among Utah ranchers between 1998 and 2009. ${ }^{1}$

\begin{tabular}{lccccc}
\hline \multicolumn{1}{c}{ Factor } & df & $n$ & $\chi^{2}$ & $P$ & Comments \\
\hline Brood herd size & 1 & 202 & 0.32 & 0.57 & NS $^{2}$ \\
Climate region & 4 & 209 & 10.53 & 0.03 & Increased preparedness in Uinta, South-Central \\
Formal education & 1 & 207 & 0.21 & 0.64 & NS \\
Drought expected & 1 & 209 & 10.45 & $<0.01$ & Increased preparedness if drought anticipated \\
Past drought actions & 1 & 209 & 11.86 & $<0.01$ & Increased preparedness with more past actions \\
Past drought impacts & 1 & 206 & 5.45 & 0.02 & Increased preparedness with more negative past impacts \\
Public permittee & 1 & 208 & 0.99 & 0.32 & NS \\
Ranching experience & 1 & 208 & 2.94 & 0.09 & NS \\
Rancher age & 1 & 208 & 2.28 & 0.13 & NS \\
\hline
\end{tabular}

${ }^{1}$ See Methods section for details on statistical analyses.

${ }^{2} \mathrm{NS}$ indicates nonsignificance at $P>0.05$. 
Table 8. Perceptions of reduced stocking rate as a risk management tactic vs. self-declarations of stocking rate levels among Utah ranchers for $2009 .^{1}$

\begin{tabular}{cllll}
\hline \multirow{2}{*}{$\begin{array}{c}\text { Use of stocking } \\
\text { rate reduction }\end{array}$} & Light & Moderate & Heavy & \multicolumn{1}{c}{ Sum } \\
\hline \multirow{2}{*}{ No } & 30 & 124 & 24 & 178 \\
& $16.9 \%$ & $69.6 \%$ & $13.5 \%$ & $100.0 \%$ \\
Yes & 63 & 163 & 17 & 243 \\
& $25.9 \%$ & $67.1 \%$ & $7.0 \%$ & $100.0 \%$ \\
\hline
\end{tabular}

${ }^{1}$ The $\chi^{2}$ test statistic was significant $(P=0.015 ; \mathrm{df}=2, n=421)$.

provided 322 ideas. Another 48 respondents felt that drought was something people had to live with and had no ideas to offer. The most common theme (68 comments, or $21 \%$ ) was the need for more policy making that was proranching and pro-drought-management. This included policies that would promote higher prices for ranch products, protection of water rights, and encouraging more cooperation between ranchers and federal land management agencies during drought. Another 68 comments concerned the need for ranchers to have improved access to extension information concerning best practices for drought management. The third most common theme was the need for more government programs that could assist producers specifically with water resources, whether it concerned water development, conservation, or distribution (42 comments or $13 \%$ ). Other themes included the need for accurate long-term drought forecasting (41 comments or $13 \%$ ), research on drought-tolerant forages (26 comments or $8 \%$ ), and more emphasis on drought-relevant range improvements and grazing management ( 23 comments or $7 \%$ ).

\section{DISCUSSION}

Descriptions of ranches and ranchers in this survey were consistent with past Utah work (Coppock and Birkenfeld 1999; Peterson and Coppock 2001). We found a wide range of broodherd sizes and two-thirds of respondents were public grazing permittees. Ranch managers were often middle-aged or older, with $70 \%$ over 51 . Eighteen percent were over 70 . Only $11 \%$ had begun to ranch in the past $10 \mathrm{yr}$. The typical operator had decades of management experience and probably witnessed two to three major droughts as a decision-maker. Although lengthy ranching experience can hone skills, age-related challenges such as declining health and pending retirement can also limit managerial innovation and financial investment (Peterson and Coppock 2001). We therefore have an aging population attempting to manage drought risk, likely exacerbated by a changing climate.

Reported impacts from the 1999-2004 drought on forage, water, and livestock made sense despite their being based on up to $10 \mathrm{yr}$ of recall. Larger impacts were observed for grazing capacity and hay yields (primary production) vs. those for cattle sale-weights (secondary production). This lagged pattern was similar to that reported for Wyoming by Bastian et al. (2006). Impact data were also internally consistent. The $25 \%$ of ranchers who noted that the 1999-2004 drought had neutral or positive effects on their operations reported more moderate resource reductions than did the $75 \%$ who noted negative drought effects. The Wyoming study did not report ranch variation in terms of drought impacts, but it is generally appreciated that this occurs (UDWR 2007-2008). From the Utah survey it appears that many ranches with access to reliable water and ample feed supplies emerged virtually unscathed from the 1999-2004 drought. Operators fortunate enough to sell surplus hay were among those who said "drought effects were positive." The vast majority of ranchers, however, were punished by the drought because they were caught in the classic trap of too many animals in combination with a scarcity of forage and water (Holechek et al. 1994; Holechek 1996b; Thurow and Taylor 1999; Ward 1999; Dunn et al. 2005).

Like the Wyoming ranchers, Utah ranchers utilized a variety of tactics to cope with drought. From Bastian et al. (2006), options employed by the final drought year in Wyoming included partial herd liquidation (44\% of respondents overall), obtaining additional grazing $(33 \%)$ or supplemental hay $(59 \%)$, participation in government assistance programs (52\%), and income diversification off-ranch (44\%). These options were also prominent in Utah.

Forty-four Utah ranchers (7\% of completed surveys) said they were less prepared for drought in 2009 than they were in 1998. Such responses may appear nonsensical, but they have value because they reflect candor among survey respondents. The low number of these respondents precluded a statistical analysis to clarify factors associated with a perceived decline in preparedness. Previous research by Peterson and Coppock (2001), however, revealed that advancing age, declining health, pending retirements, and low incomes among Utah ranchers were common constraints hindering adoption of ranch management innovations. It is likely that these factors also play a role in discouraging drought management innovation in some segments of the population, despite the risks of being less prepared for drought.

Limits on survey length precluded us from obtaining detailed information on the use of specific risk-management actions prior to 1999. Our analysis of producer response to the 19992004 drought was largely confined to assessing use of emergency response options. Most involved the need to balance supplies and demands for feed and water. Producer involvement with government programs focused on assistance with water development, obtaining free or low-cost feeds (a driedmilk program was widely publicized), or spreading out tax burdens otherwise incurred by a high annual volume of livestock sales (as in Bastian et al. 2006). The USDA also acted to open Conservation Reserve Program (CRP) lands for grazing in Utah and six other western states by 2002. The intent was to allow access to these forage supplies until the drought subsided. The CRP acreage on Utah ranches is relatively small, however, and thus use of this resource was not assessed in this survey.

It is important to note that not all crisis responses for 19992004 were mediated by government. Several fell squarely on the shoulders of producers, namely the implementation of crisis livestock sales or hay purchases, use of emergency trucking, or renegotiating bank loans. Presurvey information suggested that Utah ranchers could rely on private support from religious or social networks or other private organizations during acute times of need. The data, however, indicate that use of private charitable connections by ranchers was minimal in 1999-2004. 
By 2009 most survey respondents clearly perceived that risk management perspectives mattered. Out of 15 possible riskmanagement actions to be undertaken prior to crisis, seven were reportedly being used by over half of the sampled respondents. Of these, four actions were focused on resource development (i.e., water, forage, or hay), and two were focused on either resource conservation (reducing stocking rates) or income diversification off-ranch. Land improvement efforts included involvement in the federal Environmental Quality Incentive Program (EQIP), state Agricultural Resource Development Loan (ARDL) program, and Grazing Improvement Program (GIP); EQIP and GIP involve cost-sharing whereas ARDL involves interest-free loans. Although such activities can assist drought management, this is not the primary intent of these programs (S. Green, personal communication, October 2008). The other common response involved plans to enroll in government disaster-relief programs; eligibility for these programs is increasingly tied to requirements that producers already have feed or livestock insurance. Overall, this illustrates that risk management involves a mix of ex ante and ex post actions. Ex ante resource development can be prudent to help solve specific problems in meeting future drought challenges. Ultimate success, however, depends on whether a higher level of resource dependence so achieved is sustainable. This is a sitespecific issue, and water development is an excellent case in point (Coppock et al., 2009).

There are weather-related Internet sites such as the US Drought Monitor ${ }^{1}$, which reports current conditions, and the US Seasonal Drought Outlook ${ }^{2}$, which provides 90-d forecasts. Survey respondents were only using such tools to a modest degree; this may relate to problems of computer access for older ranchers as well as a general lack of confidence in the accuracy of weather forecasting. Results indicated that some ranchers already have drought early-warning systems focused on assessment of local snowpack and/or growing-season precipitation. Although the use of price indicators for cattle and hay may also be useful for drought-related destocking decisions, they were not mentioned much by survey respondents. It is arguable whether cattle and hay price dynamics offer enough lead time for producers to avoid a drought crisis. Technical challenges abound in creating accurate forecasts of longer-term droughts that also have local relevance (R. Gillies, personal communication, June 2010). In the meantime, the best approach may simply be conservative stocking in combination with traditional early-warning indicators.

Government drought-assistance programs have been roundly criticized by scholars and producers alike for subsidizing high stocking rates in fragile environments, contributing to resource degradation, and rewarding poor stewardship as a form of "moral hazard" (Holechek 1996b; Thurow and Taylor 1999; Ward 1999; Dunn et al. 2005; George et al. 2010). The government safety net for drought has indeed been large for many years and appears to be growing. Programs added in the 2008 Farm Bill place more emphasis on insurance and feebased compensation schemes, giving relatively less attention to ad hoc disaster responses that were previously dominant. The designs of such national programs are influenced more by farming than ranching interests, and lobbying on behalf of

\footnotetext{
${ }^{1}$ Find more on US Drought Monitor at: http://drought.unl.edu/dm/monitor.html.

${ }^{2}$ Find more on US Seasonal Drought Outlook at: http://drought.unl.edu/dm/forecast.html.
}

well-organized livestock industries is prominent (C. Son, personal communication, September 2008]. This implies that drought policy would tend to favor crop and livestock production over grazing-land conservation. The Natural Resources Conservation Service assists the Farm Services Agency and other stakeholders with the technical aspects of countywide disaster declarations that can initiate drought-relief programs. Percentage of decline in yields across all irrigated and nonirrigated forage sites due to drought is estimated via expert review, and the threshold for a disaster declaration is $\geq 50 \%$ cumulative forage loss (S. Green, personal communication, October 2008).

The UDWR (2007-2008) lists 44 state and federal drought programs across several sectors. They include state-level drought response (five programs), federal drought response (seven), federal drought mitigation (20), and federal drought monitoring (12). The UDWR (2007-2008) notes that federal relief has traditionally been a foundation of drought response and that Utah has used it as a last resort. Because the vulnerability of Utah to drought will simply increase as the population grows, the state plans to transition to more emphasis on drought mitigation.

It would be incorrect, however, to lump together all government assistance programs as contributors to unsustainable use of rangelands. Emergency relief in the form of supplemental feeds or insurance for animal death losses could contribute to heavier stocking by some producers. Ex ante rangeland investment programs such as EQIP, ARDL, or GIP, however, offer multiple benefits for sustainable rangeland management as well as drought mitigation. Participants need to document appropriate management plans that include use of conservative stocking rates (S. Green, personal communication, October 2008).

An important question is whether Utah ranchers have an expectation that government relief programs will bail them out in future droughts, and if so, whether this encourages laxity in ex ante risk management and undermines assumption of personal responsibility. This question was not directly asked in the survey because the answers were expected to have a high potential for bias. Alternatively, insights to indirectly answer this question are provided from various points in the survey. For example, even though a high percentage of respondents made use of government relief programs in 1999-2004-and plan to use them again in the future-when asked open-ended questions about what types of interventions made the biggest difference in terms of coping with drought, government relief programs were among the least mentioned. Reliable access to key water and forage resources-being able to match resource supply and demand-was what mattered most. Thus, although relief programs may have made a difference in a few circumstances or in a generally superficial way, they did not fundamentally alter the picture of who was able to best endure the drought. No respondents mentioned in reply to other openended questions that bigger and better government relief programs were needed to improve future prospects for drought management. And despite growth in government drought-relief programs, unpredictable factors can strongly affect who gets access to what benefits, and when. For example, federal disaster declarations are required to initiate local relief efforts at the county level, and this is an uncertainty. Also, droughtrelated production losses are only partially reimbursed by insurance or disaster compensation funds. It therefore makes 
little sense that a rancher would gamble on full access to generous government assistance during or after drought when one outcome of poor ex ante risk management can be financial ruin. Indeed, the majority of Utah ranchers were hit hard financially in 1999-2004.

Perhaps the most novel finding in this research is the significant increase in perceived drought preparedness (from $14 \%$ to $29 \%$ ) for Utah ranchers between 1998 and 2009. If the "prepared" group $(29 \%)$ is added to the "somewhat prepared" group $(51 \%)$ for 2009 the total is $80 \%$. Ideally, the proposition that preparedness has increased would be best confirmed by documenting ranch impacts, producer responses, and use of relief in the next drought, but this assumes the next drought will be similar to the last one. The shift in preparedness suggests that some ranchers have learned from past experience and are also willing and able to make changes. Awareness has been raised and this has been accompanied by various degrees of action. This view runs counter to some expert opinion, however, that the "bad times" are quickly forgotten, producers return to old habits from the "good times," and the net result is little progress in drought management across Utah (S. Green, personal communication, October 2008).

Is it possible that the severe (and lingering) financial consequences of being caught in the last drought trap have turned the tide a bit? Miller (2005) speaks of the "teachable moment" inspired by the same drought in southeastern Colorado; Bastian et al. (2006) mention delays in ranchers restocking to predrought levels in Wyoming. There is also theoretical support for the idea that if people perceive an important threat looming in their environment, they are more likely to take action (Baldassare and Katz 1992; O'Connor et al. 1999; Johnson and Scicchitano 2000; O'Connor et al. 2005). The explanatory factors in this study that were associated with the positive shift in drought preparedness are logical and agree with theory. These included the degree of negative experience that a producer had with the 1999-2004 drought as well as the expectation that the next drought is imminent.

Does the Utah ranching population go through periods where drought vigilance waxes and wanes over time? Probably, but this research does not shed much light on that issue given details prior to 1998 were not revealed. It could be speculated, however, that drought preparedness among ranchers might be ratcheting up over time, simply as a consequence of a heightened need to maintain profitability. Rising production costs have eroded ranch profitability for decades, and the ability of producers to reduce both costs and financial risks is becoming vital for long-term survival. Rising costs can be indicative of a growing competition for inputs such as supplemental feeds and grazing land in particular-competition that accelerates during drought. The ability to maintain profitability in an uncertain world is also related to the ability to consistently implement more intensive management. As the margins for error shrink, it is possible that ranchers lacking such commitment or abilities may become more vulnerable to drought shocks and other challenges, and thus fall by the wayside.

The prevalence of negative drought impacts being summarized by producers as the net effect of having too many cattle speaks to the idea that Utah ranchers largely see cattle-not forage-as their main economic engine. Dunn et al. (2005) noted that this mental model, combined with short- and medium-term financial incentives, inappropriate policy, and scale issues, has led to heavy stocking, poor land stewardship, and drought-management crises among South Dakota ranchers. Indeed, the beef cattle inventory in the northern Great Plains has generally increased over the last $84 \mathrm{yr}$ (Dunn et al. 2005). Several studies document that long-term profitability under drought risk is highest under conservative stocking regimes; for New Mexico desert range, conservative stocking results in the highest returns for the least risk under a forage utilization regime of 30-35\% (Holechek et al., 1999). Working in arid Australia and using a simulation-modeling approach, Foran and Stafford-Smith (1991), concluded that government support during drought favored higher stocking rates over the long term. Using a long-term experimental approach for beef cattle production in a more stable and mesic northern mixedgrass system, Dunn et al. (2010) found that compared to profitability achieved under excellent range conditions, profitability associated with low-fair to good condition classes was reduced an average of $19 \%$.

Results from this survey suggest that over half of Utah ranchers perceive they are reducing stocking levels in response to the drought experience of 1999-2004. Expert opinion also suggests that stocking rates may be trending downward across Utah, but this is thought to be more related to shifts towards a younger, better educated, and more economically diversified producer base (B. Benson and S. Green, personal communication, October 2008). Given that Utah is a state where only about $21 \%$ of the land is privately owned (LeydsmanMcGinty 2009), various factors limit the degree to which the aggregate beef herd can expand, unlike the Great Plains. Utah herd dynamics in recent decades are characterized as relatively stable (Coppock et al. 2009). Other evidence from the survey that stocking rates are indeed becoming more conservative to meet drought management goals is scanty, however. The average forage utilization on private land reported by survey respondents for recent (nondrought) years was 68\%, with wide variation, and no trend data were collected. Respondents were often confused about how to estimate utilization, which reflects real-world operational complexity as well as the likelihood of inaccuracy-training is usually required for accurate utilization assessments. But if it assumed that these utilization estimates are "reasonable," then they offer a disparity when compared to assertions that utilization should be low $(30-35 \%)$ for proper risk management in anticipation of drought. The 30-35\% figure, often quoted for the desert Southwest (as above), may be too low for more mesic Utah private lands, and in any case, utilization considered independently of the intensity of grazing management can be problematic because more intensive management can allow for higher levels of utilization (R. Banner, personal communication, June 2010). This survey did not assess the intensity of grazing management.

Although this research did not focus on the interface between drought and public grazing, federal policies do affect how ranchers cope with drought (L. Lichthardt and T. Padilla, personal communication, December 2010). Both the BLM and the USFS strive to work cooperatively with permittees to improve drought management. Regulation of public grazing becomes more conservative during droughts and drought- 
recovery periods. The BLM, however, can provide emergency access to forage under certain conditions. For example, temporary, nonpermitted grazing can be allowed where relinquishment of permits has occurred. Regulations allow for transfers of livestock and permits to better match local forage demand with supply during drought, but transfers must be validated via eligible base-property or livestock leases. A longstanding BLM policy has been to allow permittees to elect nonuse of permits for several consecutive years, and this can also be very useful under drought conditions.

\section{IMPLICATIONS}

Previous research concerning how to enhance rancher response to drought has noted a variety of constraints including the working culture, short- to medium-term financial incentives, and inappropriate policies. Such ideas are echoed here. However, there is also a marked financial disincentive for being a poor risk manager, and this is recognized by a large portion of survey respondents. It is this financial disincentive that seems to be propelling more Utah ranchers towards a greater awareness of ex ante risk-management initiatives to improve drought readiness. The pain of lingering financial crisis may be one factor that ultimately promotes sustained improvements in grazing land stewardship.

When asked how they rated themselves as risk managers, it is heartening (and realistic) that about half of the ranchers said they were "average." They prioritized interventions in the realms of policy, Extension, water resources, and drought forecasting. Ongoing research is seeking to clarify constraints for adoption of important drought-management interventions in Utah. A combination of incentives to promote conservative stocking and encourage off-ranch income diversification seems to be the foundation of change. There is a window of opportunity, and a more attentive audience, to make progress in drought management among Utah ranchers. The next big drought may be just around the corner.

\section{ACKNOWLEDGMENTS}

The author is very grateful to Susan Durham for her assistance with statistical analyses. Rick Kestle, Kerry McBride, Joel Gentillon, and the enumerators at the Utah Field Office of USDA NASS are thanked for their professional assistance with survey implementation. The study would not have been possible without the generous participation of Utah ranchers. Comments from anonymous reviewers helped improve this paper.

\section{LITERATURE CITED}

Baldassare, M., and C. Katz. 1992. The personal threat of environmental problems as predictor of environmental practices. Environment and Behavior 24(5): 602-616.

Bastian, C. T., S. Mooney, A. M. Nagler, J. P. Hewlett, S. I. Paisley, M. A. Smith, W. M. Frasier, and W. J. Umberger. 2006. Ranchers diverse in their drought management strategies. Western Economics Forum V(2):1-8.

Boykin, C. C., J. R. Gray, and D. P. Caton. 1962. Ranch production adjustments to drought in eastern New Mexico. Las Cruces, NM, USA: New Mexico Agricultural Experiment Station Bulletin 470. 41 p.
Coppock, D. L., And A. H. Birkenfeld. 1999. Use of livestock and range management practices in Utah. Journal of Range Management 52:7-18.

Coppock, D. L., D. Snyder, L. Sainsbury, M. Amin, and T. McNiven. 2009. Intensifying beef production on Utah private land: productivity, profitability, and risk. Rangeland Ecology \& Management 62(3):253-267.

Creative Research Systems. 2007. Sample Size Calculator. Available at http:// www.surveysystem.com/sscalc/htm. Accessed October 2009.

Desta, S., And D. L. Coppock. 2002. Cattle population dynamics in the southern Ethiopian rangelands, 1980-97. Journal of Range Management 55:439-451.

Desta, S., AND D. L. Coppock. 2004. Pastoralism under pressure: tracking system change in southern Ethiopia. Human Ecology 32(4):465-486.

DetTIngeR, M. D. 2003. Decadal hydrological and climate variations. In:F. H. Wagner [ED.]. Preparing for a changing climate: the potential consequences of climate variability and change. Report of the Rocky Mountain/Great Basin Regional Assessment Team for the US Global Change Research Program. Logan, UT, USA: College of Natural Resources and the Ecology Center, Utah State University. p. 39-41.

Dunn, B. H., A. J. Smart, and R. N. Gates. 2005. Barriers to successful drought management: why do some ranchers fail to take action? Rangelands 27(2):13-16.

Dunn, B. H., A. J. Smart, R. N. Gates, P. S. Johnson, M. K. Beutler, M. A. Dierssen, AND L. L. JANSESEN. 2010. Long-term production and profitability from grazing cattle in the northern mixed grass prairie. Rangeland Ecology \& Management 63(2):233-242.

Foran, B. D., and D. M. Stafford-Smith. 1991. Risk, biology and drought management strategies for cattle stations in Central Australia. Journal of Environmental Management 33(1):17-33.

George, M. R., R. E. Larsen, N. M. McDougald, C. E. Vaughn, D. K. Flavell, D. M. Dudley, W. E. Frost, K. D. Striby, and L. C. Forero. 2010. Determining drought on California's Mediterranean-type rangelands: the noninsured crop disaster assistance program. Rangelands 32(3):16-20.

Godfrey, E. B. 1992. The beef industry in the economy of Utah. Logan, UT, USA: Utah Agricultural Experiment Station Report 143. $49 \mathrm{p}$.

Hayes, M. J., O. V. Wilhelmi, And C. L. Knutson. 2004. Reducing drought risk: bridging theory and practice. Natural Hazards Review May:106-113.

HoleCHEK, J. L. 1996a. Financial returns and range condition on southern New Mexico ranches. Rangelands 18(2):52-56.

HoleCHECK, J. L. 1996b. Drought in New Mexico: prospects and management. Rangelands 18(6):225-227.

Holechek, J. L., J. Hawkes, And T. D. Darden. 1994. Macro economics and cattle ranching. Rangelands 16(3):118-123.

Holecheck, J. L., M. Thomas, F. Molinar, and D. Galt. 1999. Stocking desert rangelands: what we've learned. Rangelands 21(6):8-12.

Jacobs, K. L., G. M. Garfin, and B. J. Morehouse. 2005. Climate science and drought planning: the Arizona experience. Journal of the American Water Resources Association 41(2):437-445.

Johnson, R. J., AND M. J. Scicchitano. 2000. Uncertainty, risk, trust, and information: public perceptions of environmental issues and willingness to take action. Policy Studies Journal 28(3):633-647.

Leydsman-McGinty, E. I. 2009. Land ownership of Utah. In: R. E. Banner, B. D. Baldwin and E. I. Leydsman-McGinty [CooRD.]. Rangeland resources of Utah. Logan, UT, USA: Cooperative Extension Service, Utah State University in cooperation with the Utah Governor's Public Lands Policy Coordination Office. p. 9-23.

MilLer, M. 2005. Drought effects on the ranching industry in southeastern Colorado. Rangelands 27(2):17-18.

Molinar, F., H. de Souza Gomes, J. L. Holecheck, D. Galt, and L. Barraza-Pacheco. 1999. Applied range research needs in the next century. Rangelands 21(4):8-15.

[NDMC] National Drought Monitoring Center. 2010. Available at: http://www. drought.unl.edu/pubs/. Accessed May 2010.

O'Connor, R. E., R. J. Bord, and A. Fisher. 1999. Risk perception, general environmental beliefs, and willingness to address climate change. Risk Analysis 19(3):461-471.

O'Connor, R. E., B. Yarnal, K. Dow, C. Jocoy, and G. Carbone. 2005. Feeling at risk matters: water managers and the decision to use forecasts. Risk Analysis 25(5):1265-1275. 
Peterson, R., and D. L. Coppock. 2001. Economics and demographics constrain investment in Utah private grazing lands. Journal of Range Management 54:106-114.

Schwinning, S., J. Belnap, D. Bowling, and J. EhLerInger. 2008. Sensitivity of the Colorado Plateau to change: climate, ecosystems, and society. Available at: http://www. ecology and society.org/volXX/issYY/artZZ/. Accessed May 2010.

Thurow, T. L., and C. A. Taylor. 1999. Viewpoint: the role of drought in range management. Journal of Range Management 52(5):413-419.

[UAS and UDAF] Utah Agricultural Statistics and Utah Department of Agriculture and Food. 2004. Annual report. Salt Lake City, UT, USA: National Agricultural Statistics, Utah Field Office, USDA. $101 \mathrm{p}$.

UAS AND UDAF. 1980-2009. Annual reports. Salt Lake City, UT, USA: National Agricultural Statistics, Utah Field Office, USDA. ca 150 p. (varies by issue).
[UDWR] Utah Division of Water Resources. 2007-2008. Drought in Utah: learning from the past-preparing for the future. Available at: http://water.utah.gov/ DroughtReport/Drought2008A.pdf. Accessed May 2010.

UeBERSAX, J. S. 2006. User guide for the marginal homogeneity program (vers. 1.1). Statistical methods for rater agreement. Available at: http://johnuebersax.com/stat/mh.htm. Accessed November 2009.

Wagner, F. H., AND C. K. BaldWin. 2003. Cultivated agriculture and ranching. In: F. H. Wagner [ED.]. Preparing for a changing climate: the potential consequences of climate variability and change. Report of the Rocky Mountain/Great Basin Regional Assessment Team for the US Global Change Research Program. Logan, UT, USA: College of Natural Resources and the Ecology Center, Utah State University. p. 113-129.

WARD, N. 1999. Ranchers need support for sustainable ranching: what government can do-a rancher's perspective. Rangelands 21(3):13-17. 